\title{
Distribution of fibronectin in the rectal mucosa
}

\author{
DL SCOTT, CJ MORRIS, AE BLAKE,* TS LOW-BEER, ${ }^{*}$ KW WALTON \\ From the Department of Investigative Pathology, Medical School, University of Birmingham, and \\ *Selly Oak Hospital, Birmingham
}

SUMMARY Fibronectin is a glycoprotein of high molecular weight present in tissues, plasma, and tissue fluids. Its distribution in the rectal mucosa was studied by immunofluorescent and immunoperoxidase techniques using a monospecific antiserum. Immunofluorescent reactivity for fibronectin was present in the normal rectal mucosa of control subjects in epithelial cells, on basement membranes, and as a loose cribriform network of extracellular reactivity in the lamina propria that codistributed with histochemically demonstrable reticulin. Fibronectin was demonstrated immunoelectromicroscopically on collagen fibres, on smooth muscle cells and within and between columnar epithelial cells. In the rectal mucosa of patients with colitis with marked inflammatory changes, fibronectin appeared thickened and more prominent when present on basement membranes and as sparse strands between inflammatory cells infiltrating the lamina propria. In patients with longstanding colitis and less inflammatory cell infiltration there was a diffuse increase in fibronectin which was densely and uniformly present throughout the lamina propria. Fibronectin is a structural component of the rectal mucosa and changes in its distribution may form an important part of the local reaction to inflammatory bowel disease.

Fibronectin, a high molecular weight glycoprotein, is synthesised by mesenchymal cells and secreted by them into their environment. It is present both in the tissues and plasma. The tissue and plasma forms of fibronectin have biochemical differences, ${ }^{1}$ but are immunologically indistinguishable. ${ }^{2}$ Studies of the distribution of fibronectin in normal human tissues ${ }^{3} 4$ have shown that it is a widely distributed and an important component of the connective tissue matrix.

Connective tissue components are structurally important in the rectal mucosa. The distribution of some of these components in the rectal mucosa has been extensively studied-for example, that of fibres

Accepted for publication 26 November 1980 showing the histochemical characteristics of reticulin. ${ }^{56}$ Our previous investigations ${ }^{7}$ have shown that fibronectin is, in some tissues, codistributed with immature collagen and reticulin. In this study we have defined the distribution of fibronectin in the rectal mucosa, evaluated its relation to other connective tissue components and investigated the changes that occur in its distribution in colitis.

\section{Material and methods}

COLLECTION OF SPECIMENS

Rectal biopsies were taken from the patients detailed in the Table. Biopsy specimens were snap-frozen in liquid nitrogen and subsequently stored at $-80^{\circ} \mathrm{C}$, fixed in $95 \%$ ethanol at $4{ }^{\circ} \mathrm{C}$, or fixed in $10 \%$ neutral

\section{Details of patients studied}

\begin{tabular}{|c|c|c|c|c|}
\hline Group & No & $\operatorname{Sex}(M: F)$ & Age range (yr) & Comments \\
\hline Controls & 6 & $2: 4$ & $26-70$ & $\begin{array}{l}5 \text { patients with the "irritable bowel" syndrome with } \\
\text { normal sigmoidoscopic appearances, normal } \\
\text { radiology and normal conventional histology; } \\
1 \text { patient with an adenomatous polyp but no } \\
\text { other abnormalities }\end{array}$ \\
\hline $\begin{array}{l}\text { Active ulcerative colitis } \\
\text { Active Crohn's colitis }\end{array}$ & $\begin{array}{l}8 \\
2\end{array}$ & $\begin{array}{l}1: 7 \\
0: 2\end{array}$ & $\left.\begin{array}{l}16-71 \\
21-55\end{array}\right\}$ & Different stages of disease activity \\
\hline $\begin{array}{l}\text { Previous ulcerative colitis; now } \\
\text { inactive }\end{array}$ & 2 & $1: 1$ & $26-42$ & $\begin{array}{l}\text { Asymptomatic with normal sigmoidoscopic } \\
\text { appearances, normal radiology, and normal } \\
\text { conventional histology when seen }\end{array}$ \\
\hline
\end{tabular}


formol-saline at room temperature. Diagnosis was based on the clinical findings, radiological changes (all patients had had a barium enema within 3 months of the biopsy), sigmoidoscopic examination and the histological changes. In addition, small pieces of the rectal biopsy specimens from 2 control patients, and from a patient with Crohn's disease, were removed for staining by the immunoperoxidase method, before freezing or fixation. Informed consent was obtained from all patients before biopsies were taken.

\section{PREPARATION OF ANTIFIBRONECTIN ANTISERUM}

Human fibronectin was isolated from plasma by affinity chromatography using gelatin coupled to cyanogen bromide-treated Sepharose 4B (Pharmacia Ltd) according to the method of Engvall and Ruoslahti $^{8}$ as modified by Dessau et al. ${ }^{9}$ The fibronectin was further purified by the removal of minor contaminating proteins by chromatography on a Sephacryl S300 column (Pharmacia Ltd) eluted with a buffer containing $0 \cdot 1 \mathrm{M}$ tris (hydroxymethyl) aminomethane (TRIS) $0 \cdot 1 \quad M$ sodium chloride adjusted to $\mathrm{pH} 7 \cdot 4$ with $\mathrm{HCl}$. The purity of the final product was assessed by sodium dodecyl sulphate polyacrylamide gel electrophoresis and by 1- and 2-dimensional immunoelectrophoresis using antiserum to whole human serum (Burroughs Wellcome Ltd).

The purified fibronectin was used to raise antisera in rabbits. It was initially homogenised in Freund complete adjuvant and injected both intravenously and subcutaneously: later injections were given subcutaneously without adjuvant in a dosage schedule previously described. ${ }^{10}$ Unwanted antibodies were removed by adsorption of the antisera using the fibronectin-free supernatant from the first step of the isolation procedure.

\section{IMMUNOHISTOLOGICAL REAGENTS}

Samples of the fibronectin antiserum were labelled with fluorescein isothiocyanate as described by Nairn ${ }^{11}$ or with horseradish peroxidase as described by Nakane and Kawaoi. ${ }^{12}$ Antisera to human fibrinogen, immunoglobulins (IgG, IgA and IgM), complement $\left(C^{\prime} 3\right)$ (from the Immunodiagnostic Research Laboratory, Department of Immunology, University of Birmingham) and factor XIIIa (from Hoechst Ltd) were used both labelled or unlabelled with fluorescein as described above. Sheep antiserum to rabbit immunoglobulin was also obtained from the Immunodiagnostic Research Laboratory, University of Birmingham, and was unlabelled or labelled with fluorescein. All the antisera used were monospecific.
PREPARATION OF SECTIONS FOR

FLUORESCENT AND LIGHT MICROSCOPY

Unfixed snap-frozen tissue was used to preparê⿳亠丷厂 frozen sections as previously described. ${ }^{13}$ Tissues fixed in cold alcohol were used to prepare section£ for immunofluorescent examination by the method o Saint-Marie. ${ }^{14}$ Tissues in formol saline were em bedded in wax for the preparation of $6 \mu \mathrm{m}$ sections

IMMUNOHISTOLOGICAL METHODS

The distribution of fibronectin, fibrinogen, immuno $\overrightarrow{\vec{\Delta}}$ globulins, complement and factor XIIIa were soughf by direct and indirect immunofluorescence using कृ Zeiss 514 Incident Light Fluorescence Microscope When indirect methods were used, normal rabbif serum and fluorescein-conjugated sheep antirabbit immunoglobulin were used as controls. Direct anto indirect immunofluorescent methods gave aro identical appearance.

\section{OTHER HISTOLOGICAL METHODS}

The appearances seen with the immunohistologicat methods described above were compared with those seen in corresponding sections stained with haema:toxylin and eosin (H and E); van Gieson's fluido Gordon and Sweet's method for reticulin;15 the Martius Scarlet Blue (MSB) technique described b. Lendrum et al.;16 and the picropolychrome methoo of Herovici. ${ }^{17}$

IMMUNOPEROXIDASE METHODS AND ELECTRONMICROSCOPY

As soon as possible after removal, small pieces of bowel ( $1 \mathrm{~mm}$ cubes) were placed in peroxidaseof labelled rabbit antihuman fibronectin antiserung diluted 1.3 with phosphate-buffered saline (PBS) a $4^{\circ} \mathrm{C}$. The tissue was left in contact with the antiserund for $3 \mathrm{~h}$ and then was gently washed 3 times with PBS at $4^{\circ} \mathrm{C}$. The tissue was then fixed in phosphateo buffered $2.5 \%$ glutaraldehyde (pH 7.2) for $15 \mathrm{~min}$ at $4^{\circ} \mathrm{C}$, followed by further washing in PBS and thero in $0.05 M$ TRIS $\mathrm{HCl}(\mathrm{pH} \mathrm{7.4)}$ at room temperature Sites of peroxidase activity were revealed histos chemically by the diaminobenzidine method of Graham and Karnovsky. ${ }^{18}$ The tissue was washed inn $0.05 M$ TRIS $\mathrm{HCl}$ buffer, post-fixed in $2 \%$ osmiunz tetroxide in distilled water for $1 \mathrm{~h}$, dehydrated in graded alcohols and embedded in Spurr's lowe viscosity epoxy resin. ${ }^{19}$

\section{Results}

DISTRIBUTION OF FIBRONECTIN IN THE RECTAL WALL IN CONTROLS

By immunofluorescence

In biopsies taken from the control subjects, fibros 


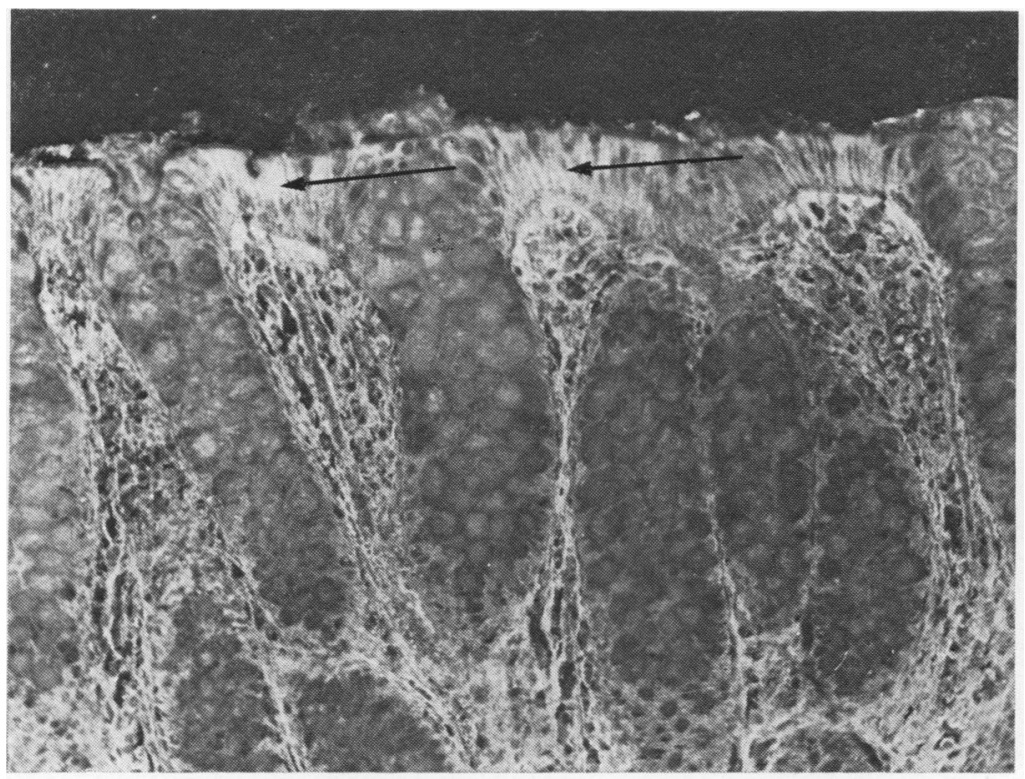

$1 \mathrm{a}$

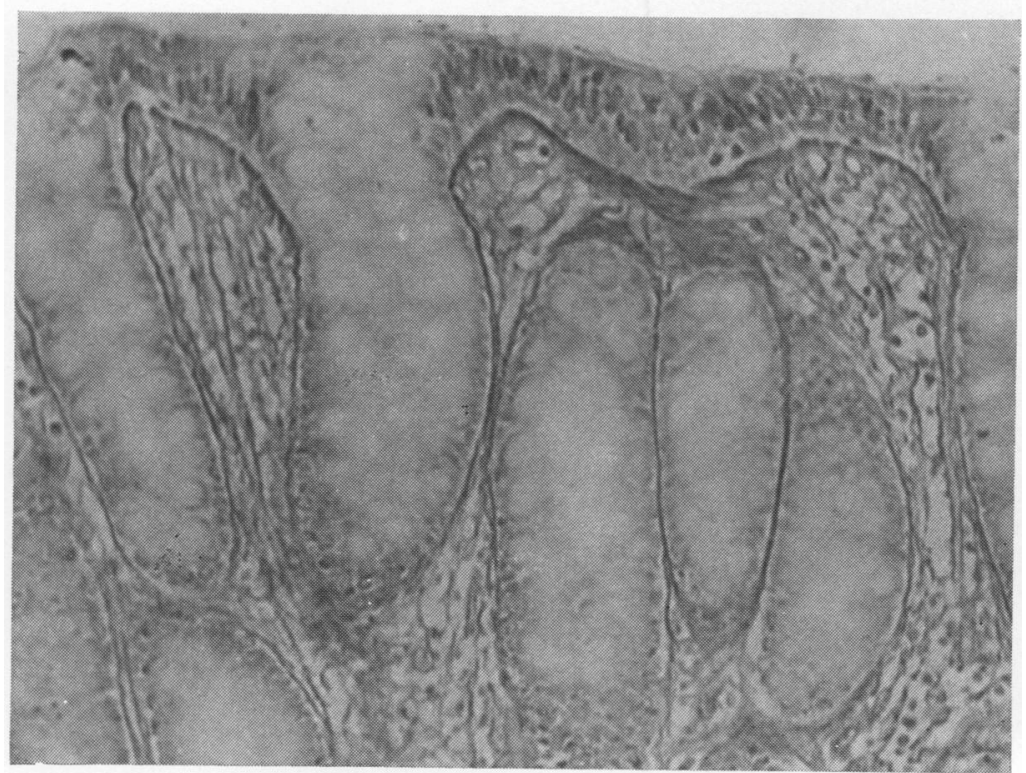

Fig. 1 (a) Rectal mucosa from a control patient showing the immunofluorescent distribution of fibronectin; there is reactivity in a cribriform distribution throughout the lamina propria, on basement membranes, and in some epithelial cells (arrowed). (b) Sequential section from same patient stained for reticulin. $\times 180$

nectin was demonstrable by immunofluorescence in the cytoplasm of glandular epithelial cells at the apices of crypts but not in the nuclei of these cells. Mucus-secreting cells in the crypts failed to react with the antiserum, appearing as "black holes." There was also reactivity for fibronectin on the basement membranes underlying the epithelial cells and of small blood vessels in the wall of the rectum The most prominent distribution was in the lamina propria of the mucosa and in the submucosa, in the form of a loose cribriform network of extracellular fluorescence surrounding lymphoid follicles and individual cells (Figs. $1 \mathrm{a}$ and $2 \mathrm{a}$ ). Smooth muscle cells of the muscularis mucosa and of the muscular coat of 

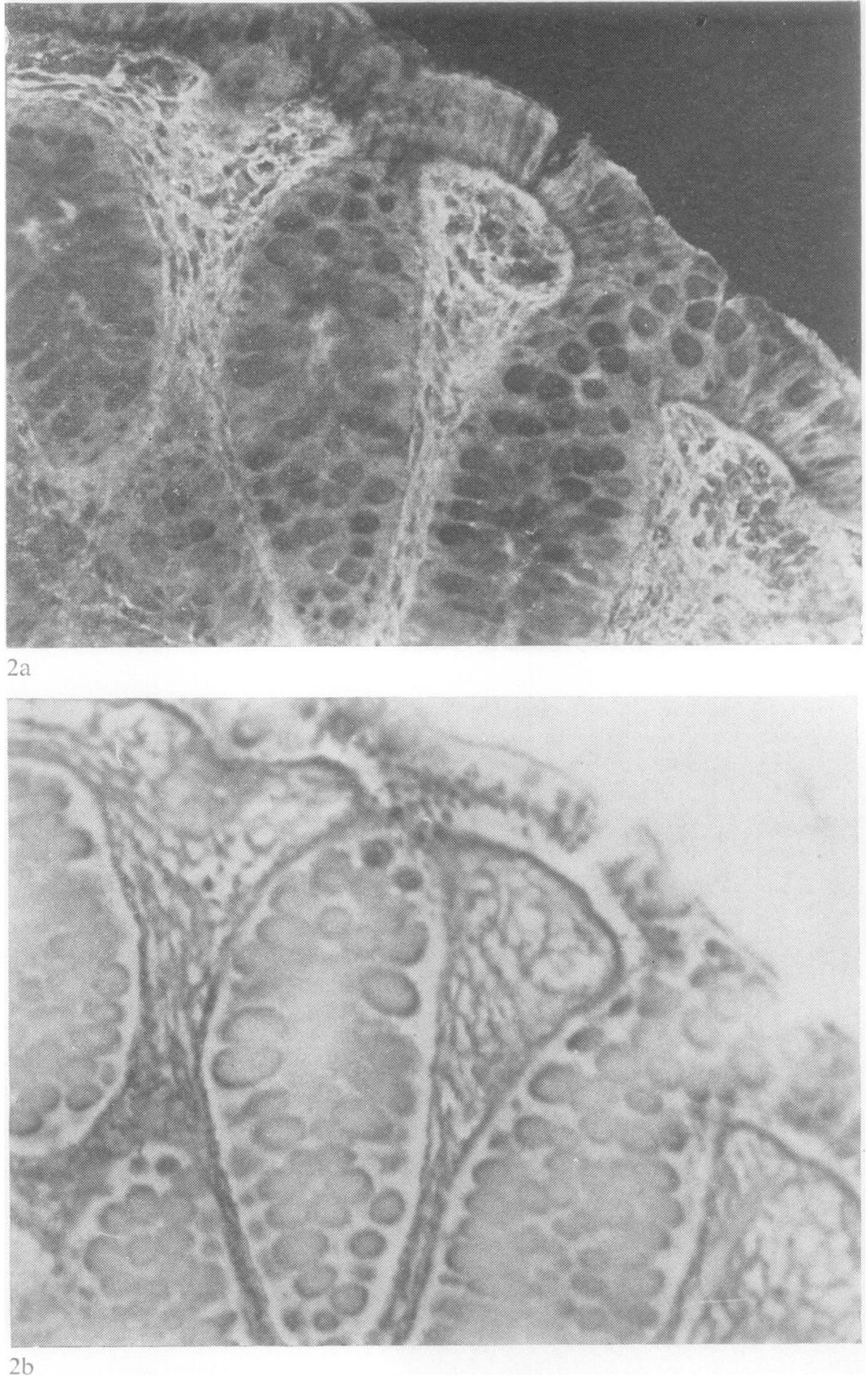

Fig. 2 Sequential sections through the rectal mucosa showing: (a) immunofluorescent distribution of fibronectin with a cribriform pattern of distribution in the lamina propria; $(b)$ reticulin codistributing with fibronectin; (c) staining with Martius Scarlet Blue $(M S B)$ - the arrows indicate? areas staining blue with this technique. $\times 300$

the bowel also showed diffuse reactivity. The immunofluorescent distribution of fibronectin in the mucosa corresponded closely to that of reticulin demonstrated by conventional silver stains (Figs. $1 \mathrm{~b}$ and $2 \mathrm{~b}$ ). Similarly, sections stained with a trichrome stain (MSB) showed the areas reacting for fibronectin staining bright blue (Fig. 2c).
By immunoelectronmicroscopy

In material treated first with horseradish peroxidase labelled antifibronectin and then with diamino $\frac{\vec{D}}{\mathbb{D}}$ benzidine, the electron-dense reaction product which? identifies the antibody bound to fibronectin was found in a distribution similar to that described above. Discrete deposits were found intracellularlyo 


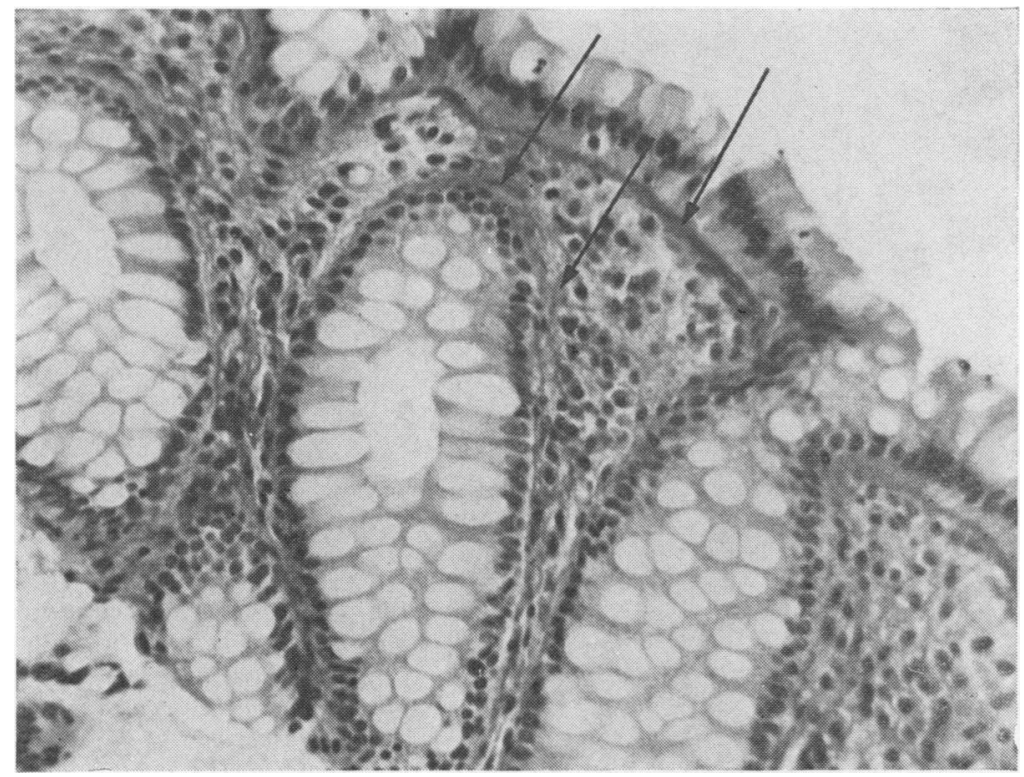

2c

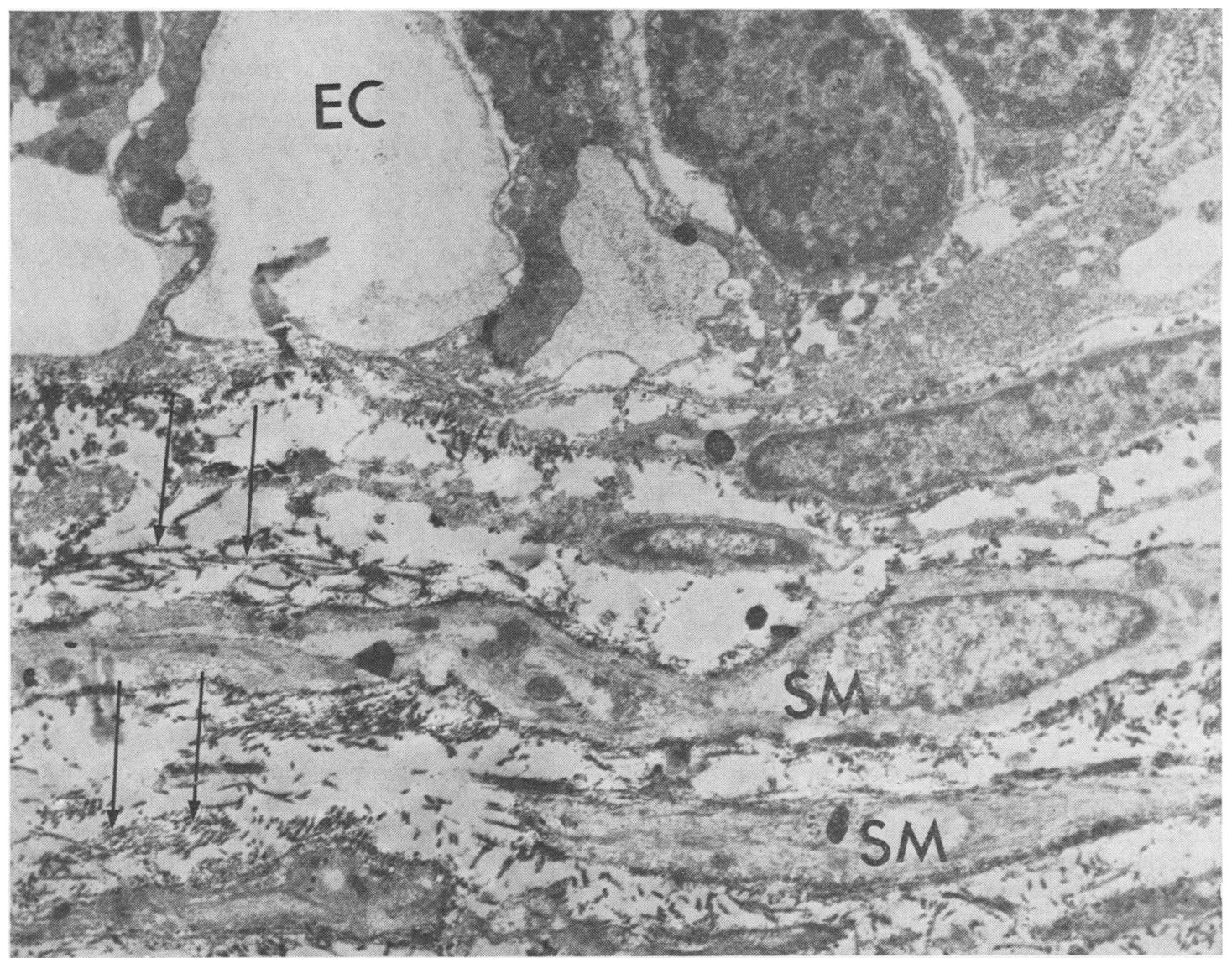

Fig. 3 Low power electronmicrograph showing immunoperoxidase reactivity for fibronectin in the basal portion of the epithelial cells and the lamina propria in a control patient; reaction product is seen on the plasma membrane of the smooth muscle cells (SM) and on collagen (arrowed) in the lamina propria. The site of the epithelial cells is indicated (EC). $\times 15000$ 


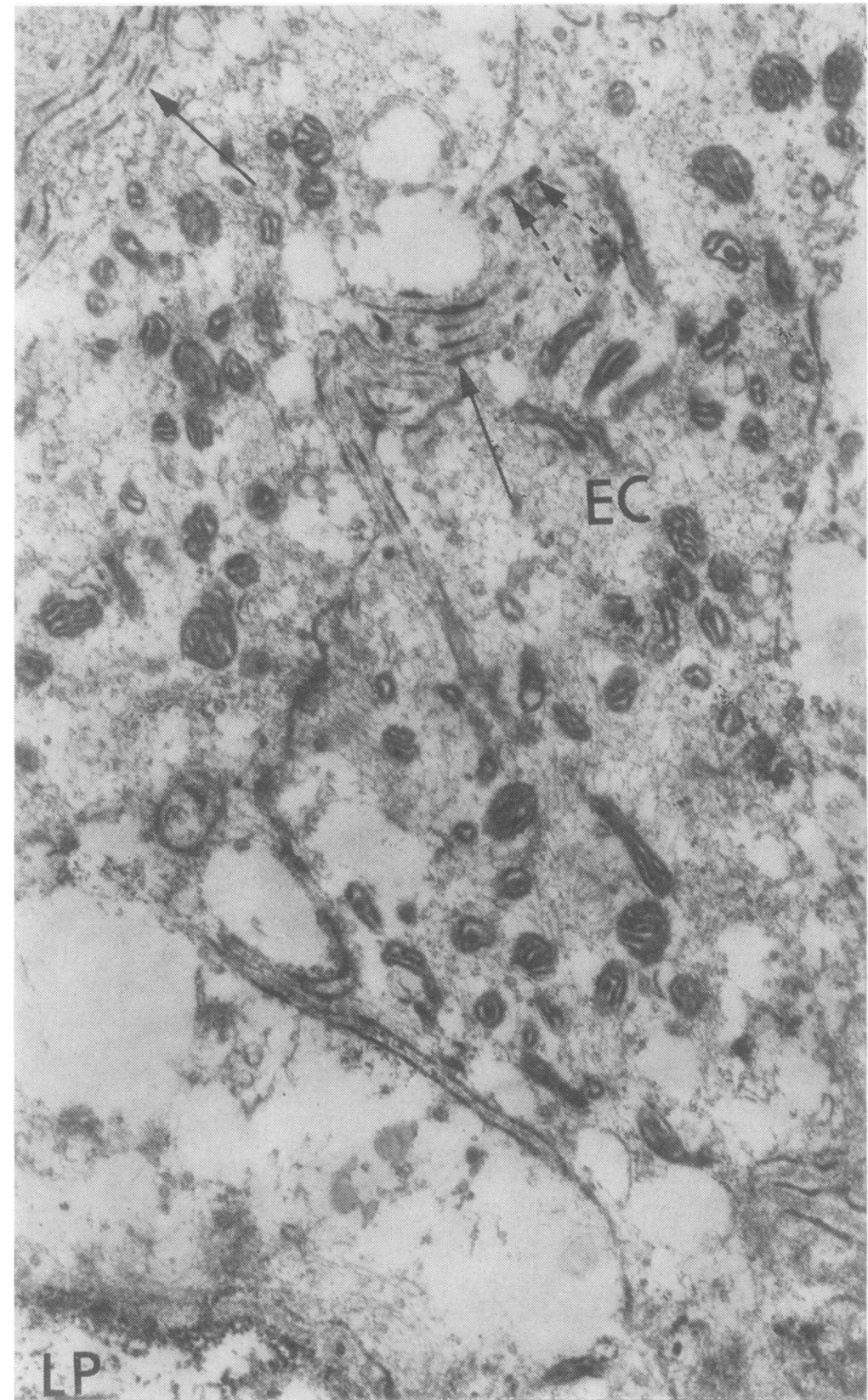

Fig. 4 High power electronmicrograph showing immunoperoxidase reactivity for fibronectin on the opposing plasma membranes of the epithelial cells $(E C)$ in a control patient. The reaction product is deposited discontinuously on the membranes (arrowed). There is some intracellular deposition (broken arrows). The position of the lamina propria $(L P)$ is indicated. $\times 31000$

within epithelial cells but not within mucus-secreting cells. Where intracellular deposits were present, it was not possible to determine whether these were associated with particular cell organelles. Intercellular fibronectin identified by peroxidase staining also appeared between the columnar epithelial cells as irregularly spaced deposits.
In the lamina propria and submucosa, the reaction? product was associated with collagen fibrils (Fig. 3 ), 0 the deposits showing evidence of periodicity of distribution. Smooth muscle cells of the muscularis@ mucosa showed an almost continuous fine surface deposit of reaction product, with intermittent promi- $-\bar{\sigma}$ nent dense deposits at irregular intervals, around 

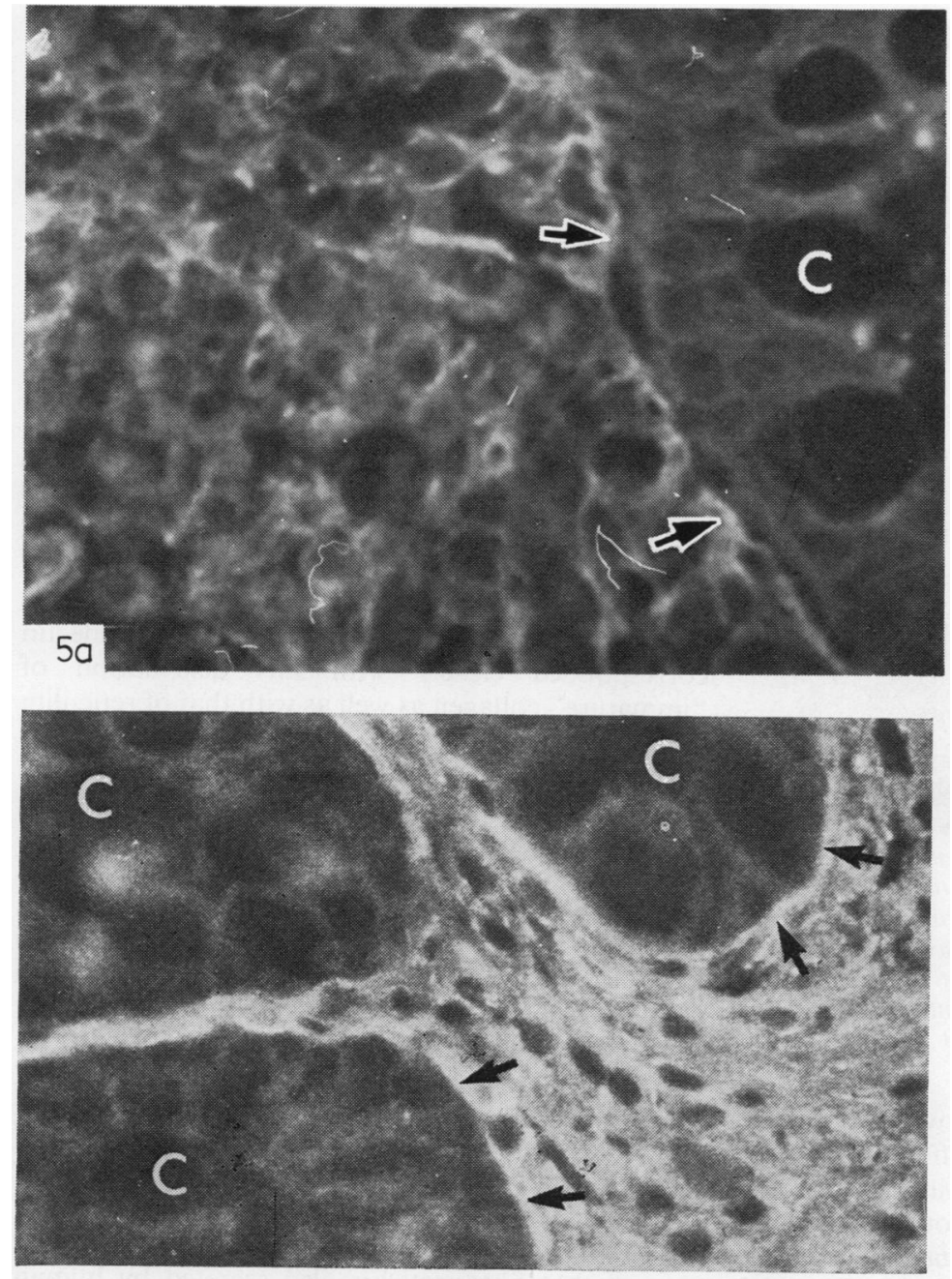

Fig. 5 Comparable transverse sections of the rectal mucosa showing the immunofluorescent distribution of fibronectin: (a) a patient with acute active ulcerative colitis with a marked inflammatory cell infiltration of the rectal mucosa showing a reticular distribution of fibronectin in the lamina propria; (b) a patient with longstanding ulcerative colitis and only minimal inflammatory cell infiltration of the rectal mucosa showing a diffuse distribution of fibronectin in the lamina propria surrounding negatively reacting inflammatory cells. Both cases showed reactivity on basement membranes (arrowed). The sites of the crypts are indicated $(C) . \times 1200$

$5 \mathrm{~b}$

the outer surface membranes of the cells (Fig. 4).

DISTRIBUTION IN THE RECTAL WALL IN ACTIVE COLITIS

While the broad pattern of distribution of fibronectin was retained in colitic biopsies, certain differences from the "normal" were observed which appeared to correlate with the duration and severity of the bowel disease. With increasing disease duration there was an apparent increase in fibronectin as judged either by immunofluorescence or immunoelectronmicroscopy.

In the earliest stages of colitis (two patients with ulcerative colitis for three and six months respectively), the delicate cribriform pattern seen in healthy bowel was preserved. However, in patients with disease of greater duration and severity (four patients with ulcerative colitis; one patient with Crohn's colitis, all with symptoms for 2-4 yr) there was thickening and prominence of the fibronectin present on the basement membrane and as sparse strands between the inflammatory cells infiltrating the lamina propria (Fig. 5a). There was also a thickening and coarsening of the reticular pattern seen elsewhere in the submucosa. Sigmoidoscopy showed a friable mucosa and conventional histology showed a marked inflammatory cell infiltrate with many polymorphonuclear leucocytes.

In biopsies from three patients with chronic colitis (two with ulcerative colitis and one with Crohn's disease) and symptoms for 2.5-19 yr, conventional histology showed minimal cellular infiltration.

Sigmoidoscopy showed an intact mucosa in two of 


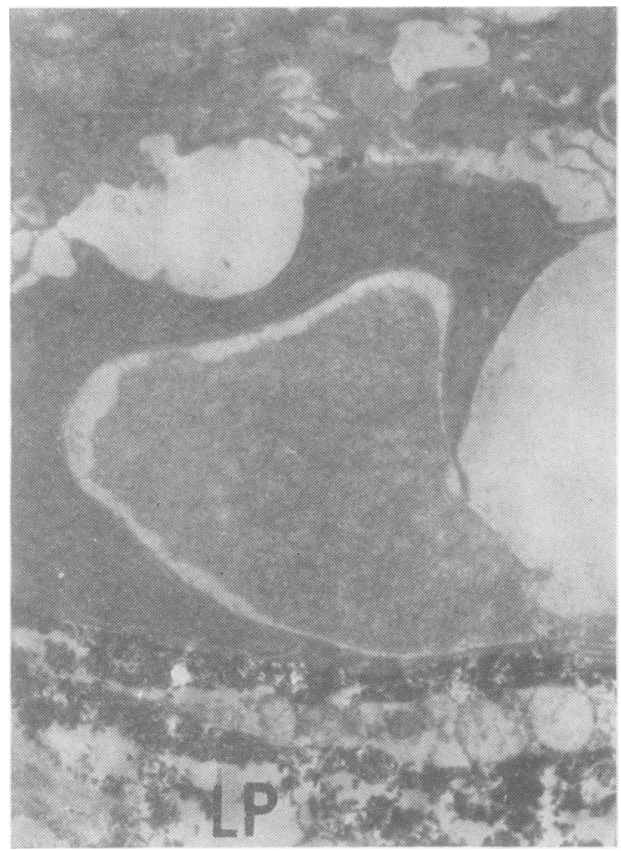

Fig. 6 High power electronmicrograph showing immunoperoxidase reactivity for fibronectin in the rectal mucosa of a patient with longstanding Crohn's colitis. The reaction product is present in increased amounts in the lamina propria $(L P)$ compared to that in the controls. This patient had diffuse immunofluorescent reactivity throughout the lamina propria. $\times 31000$

these three patients. These biopsies, when examined by immunofluorescence, showed a diffuse increase of distribution of fibronectin which was densely and almost uniformly present throughout the lamina propria, surrounding the scanty negatively-reacting inflammatory cells in this area (Fig. 5b). Material from one of these patients, examined by immunoelectronmicroscopy, showed the relation of fibronectin to the epithelial cells, smooth muscle cells and collagen to resemble that seen in controls. However, the amount of reaction product in the lamina propria was markedly increased (Fig. 6).

\section{OTHER PROTEINS IN RECTAL BIOPSIES}

Sections examined after treatment with antisera to immunoglobulins $A, G$ and $M$ and to the $C^{\prime} 3$ component of complement showed the expected presence of $\operatorname{IgA}$ and occasionally of the other immunoglobulins and $C^{\prime} 3$ in relation to cells in lymphoid follicles in the bowel wall. The distribution of these proteins was not related to that of fibronectin.

In certain pathological situations such as rheumatoid synovitis or atherosclerotic lesions, fibronectin is codistributed with fibrin. ${ }^{7}$ But fibrin demonstrable by the MSB technique was not present $\stackrel{0}{\overrightarrow{0}}$ in significant amounts in the rectal biopsies examined.. In addition there was no relation between the $\overrightarrow{\vec{F}}$ immunofluorescent reactivity of fibronectin and that of fibrinogen or factor XIII (fibrin stabilising factor)등 in sequential sections of rectal biopsies from either $\overline{\frac{5}{5}}$ the controls or patients with colitis.

\section{RELATION BETWEEN FIBRONECTIN AND}

HISTOLOGICALLY DEMONSTRABLE COLLAGEN $\vec{\circ}$ Mature collagen (in the sense of coarse fuchsinophil $\overrightarrow{-}$ fibres reacting with van Gieson's fluid or the red.్ల component of Herovici's picropolychrome stain) was absent in the lamina propria of the mucosa and in the submucosa in control biopsies. On the other hand $\stackrel{\omega}{+}$ the delicate connective tissue at these sites stained. blue with the picropolychrome method or with the MSB technique which are characteristics of "imma-o ture" collagen. The distribution of fibronectin? corresponded closely with this distribution of $\vec{c}$ "immature" collagen as well as with that of reticulin, as described above.

In patients with chronic colitis showing thickening $\ddot{\oplus}$ and accentuation of fibronectin staining (see Fig. 5b) there was evidence of maturation of the collagen ato these sites into coarse fibres staining pink with van Gieson's fluid and the picropolychrome stain. Thiso is in contrast to other tissues where fibronectin has been found to be codistributed with immature $\varrho$ collagen in areas undergoing fibrosis, but no longer $\overrightarrow{\vec{O}}$ to be associated with dense fibrous scar tissue.?

\section{Discussion}

Fibronectin is known to be a secretory product of many types of cells, including endothelial cells, fibroblasts, and smooth muscle cells. ${ }^{2}$ Our results suggest that fibronectin is also secreted by human $\frac{\circ}{3}$ rectal epithelial cells. The distribution found in and around these cells is consistent with the known role of this protein in serving as a physiological adhesive $\frac{7}{0}$ securing the attachment of cells to underlying substrate and to one another. ${ }^{2}$ It seems probable that $\mathrm{N}$ the fibronectin we have found to be associated with $N$ the basement membranes of the rectal mucosa is also $N$ subserving this kind of purpose. Fibronectin has $\omega$ been described as a component of basement membrane in other organs. ${ }^{20-21}$

Our findings further suggest that the lamina $\stackrel{\odot}{\Phi}$ propria and submucosa of the rectum resemble other + loose areolar tissues in consisting of fibres or $\frac{0}{0}$ fibrillar material with different staining reactions $\overrightarrow{\mathbb{D}}$

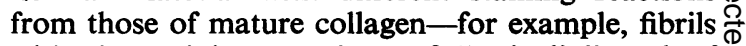
with the staining reactions of "reticulin" and of $\varrho$ immature collagen as well as of fibronectin. It is now?

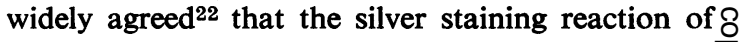


"reticulin" does not detect a specific variety of fibre, but is merely a property of a matrix bound to collagen. Isolated "reticulin" has been shown to contain non-collagenous glycoproteins ${ }^{23}$ one of which may be fibronectin, as the present study and our previous observations suggest.

This hypothesis would account for our finding of a codistribution of fibronectin, reticulin and "immature" collagen in the bowel wall. Fibronectin and reticulin have been found to be similarly codistributed in other tissues ${ }^{4}$ and reticulin and type III collagen have also been reported as having similar distributions to one another elsewhere in the body. ${ }^{24-26}$ In the rectum, the presence of bowel disease appears to stimulate the local production of fibronectin in the lamina propria and submucosa but the changes, like other histological features of chronic inflammation at this site, were not specific for ulcerative colitis or Crohn's disease.

Our observations suggest that changes in fibronectin in the bowel wall occur as a sequence: in the initial stages of inflammatory bowel disease the dilicate cribriform distribution of fibronectin found in health is unaltered; subsequently a coarse reticular pattern develops and this may be followed by a diffuse deposition of fibronectin. Such sequential changes suggest that fibronectin forms part of the response of the rectal mucosa to inflammatory change in the large bowel. Similar changes have been observed to affect reticulin at this site. However, there is controversy as to the temporal relation of such changes to colitis. Donnellan ${ }^{5}$ suggested that changes in reticulin appeared early in the course of colitis whilst Gonzalez-Licea and Yardley ${ }^{6}$ considered that they occurred at a later stage.

Changes in the tissue distribution of fibronectin occur in diverse pathological conditions and are not specific for a single disease, the pattern of deposition probably being determined by the high affinity of fibronectin for fibrin(ogen) and for collagen and its derivatives. ${ }^{2}{ }^{8}$ In some tissues, such as the acutelyinflamed synovium of rheumatoid arthritis ${ }^{7}$ fibronectin is codistributed with (presumably by adsorption upon) fibrin and immature collagen but is not related in distribution to mature collagen (fibrous scar tissue). In the cirrhotic liver ${ }^{20}$ fibronectin is again associated with the early but not the later fibrotic reaction.

In contrast, in rectal mucosa, neither fibrin deposition nor severe fibrosis are typical of colitis. The persistent relation of fibronectin to components of the loose connective tissue of the submucosa is thus peculiar to this site. The increase of fibronectin with the duration and severity of bowel disease is not "specific" for a given variety of colitis. It may, however, be useful as a means of indirectly assessing a continuing disease process in rectal biopsies.

\section{References}

${ }^{1}$ Yamada KM, Kennedy DW. Fibroblast cellular and plasma fibronectin are similar but not identical. $J$ Cell Biol 1979;80:492-8.

${ }^{2}$ Yamada KM, Olden K. Fibronectins-adhesive glycoproteins of cell surface and blood. Nature 1978;275:17984.

${ }^{3}$ Stenman S, Vaheri A. Distribution of a major connective tissue protein, fibronectin, in normal human tissues. $J$ Exp Med 1978;147:1054-64.

- Linder E, Stenman S, Lehto VP, Vaheri A. Distribution of fibronectin in human tissues and relationship to other connective tissue components. Ann NY Acad Sci 1978; 312:151-9.

${ }^{5}$ Donnellan WL. Early histological changes in ulcerative colitis. Gastroenterology 1966;50:519-40.

${ }^{6}$ Gonzalez-Licea A, Yardley JH. Nature of the tissue reaction in ulcerative colitis. Gastroenterology 1966;51: 825-38.

${ }^{7}$ Scott DL, Wainwright AC, Walton KW, Williamson $\mathrm{N}$. Significance of fibronectin in rheumatoid arthritis and osteoarthrosis. Ann Rheum Dis 1981;40:142-51.

${ }^{8}$ Engvall E, Ruoslahti E. Binding of soluble forms of fibroblast surface protein, fibronectin, to collagen. Int $J$ Cancer 1977;20:1-5

${ }^{9}$ Dessau W, Adelmann BC, Timpl R, Martin GR. Identification of the sites in collagen $a$-chains binding serum anti-gelatin factor (cold insoluble globulin). Biochem $J$ 1978;169:55-9.

${ }^{10}$ Soothill JF. Estimation of eight serum proteins by a gel diffusion precipitin technique. J Lab Clin Med 1962;59: 859-70.

${ }^{11}$ Nairn RC. Fluorescent protein tracing 3rd ed. London: Livingstone, 1969.

12 Nakane PK, Kawaoi A. Peroxidase-labelled antibody. A new method of conjugation. $J$ Histochem Cytochem 1974;22:1084-91.

${ }^{13}$ Walton KW, Williamson N. Histological and immunofluorescent studies on the evolution of the human atheromatous plaque. $J$ Atheroscler Res 1968;8:599-624.

${ }^{14}$ Saint-Marie G. A paraffin embedding technique for studies employing immunofluorescence. J Histochem Cytochem 1962;10:250-6.

15 Gordon H, Sweet HH. A simple method for the silver impregnation of reticulin. Am J Pathol 1936;12:545-51.

${ }^{16}$ Lendrum AC, Fraser DS, Slidders W, Henderson R. Studies on the character and staining of fibrin. J Clin Pathol 1962;15:401-13.

17 Herovici C. Le picropolychrome technique de coloration histologique destinée a l'étude du tissu conjonctif, normal et pathologique. Rev Franc Etud Clin Biol 1963; 8:88-9.

${ }^{18}$ Graham RC, Karnovsky MJ. The early stages of absorption of injected horseradish peroxidase in the proximal tubules of mouse kidney. Ultrastructural cytochemistry by a new technique. J Histochem Cytochem 1966;14:291302.

${ }^{19}$ Spurr AR. A low viscosity epoxy resin embedding medium for electronmicroscopy. $J$ Ultrastruct Res 1969;26:31-43.

${ }^{20}$ Hatin E, Wick G, Pencev D, Timpl R. Distribution of basement membrane proteins in normal and fibrotic human liver: collagen type IV, laminin and fibronectin. Gut 1980;21:63-71.

${ }^{21}$ Spiro RG. Nature of the glycoprotein components of 
basement membranes. Ann NY Acad Sci 1978;312:10621.

22 Puchtler H, Waldrop FS. Silver impregnation methods for reticulin fibres and reticulin: a re-investigation of their origins and specificity. Histochemistry 1978;57:177-87.

${ }^{23}$ Pras M, Glynn LE. Isolation of a non-collagenous reticulin component and its primary characterisation. $B r J$ Exp Pathol 1973;54:449-56.

${ }^{24}$ Gay S, Balleisen L, Remberger K, Fietzek PP, Adelman $B C$, Kuhn K. Immunohistochemical evidence for the presence of collagen type III in human arterial walls, arterial thrombi and in leucocytes incubated with collagen in vitro. Klin Wochenschr 1975;53:899-902.
${ }^{25}$ Remberger K, Gay S, Fietzek PP. Immunohistochemische Untersuchungen zur Kollagencharakterisierung in Lebercirrhosen. Virchows Arch (Pathol Anat) 1975;367: 231-40.

${ }^{26}$ Nowack H, Gay S, Wick G, Becker U, Timpl R. Preparation and use in immunology of antibodies specific for type I and type III collagen and procollagen. J Immuno Methods 1976;12:117-24.

Requests for reprints to: Dr DL Scott, Department of Investigative Pathology Medical School, University of Birmingham, Birmingham B15 2TJ, England. 